\title{
Prevalence of temporomandibular disorders and orofacial pain in battered women in Brazilian shelters
}

\section{Prevalência de desordens temporomandibulares e de dor orofacial em mulheres vítimas de violência}

\begin{abstract}
Purpose: To assess the prevalence of Temporomandibular Disorders (TMD) and Orofacial Pain (OFP) in women victim of domestic violence, and the impact of chronic pain in related psychosocial factors, such as depression and somatization, as well as in the women's quality of life.

Methods: A convenience sample of 20 women in a situation of domestic violence who accessed support institutions were voluntarily interviewed. OFP and related psychosocial factors were assessed by using the RDC/TMD (Research Diagnostic Criteria for TMD) Axis II, and the history of physical and sexual abuse by the S/PAHQ (Sexual and Physical Abuse History Questionnaire).

Results: Eighty percent of women victim of violence showed chronic pain, varying from 1 to 3 on a four-point scale $(0$ to 3$), 65 \%$ showed severe depression, and $60-70 \%$ reported evere somatization with or without pain, respectively. In addition, $85 \%$ reported pain in the face, temples and ear in the last month with a recurrent pattern.

Conclusion: Data indicated high prevalence of TMD and OFP in this sample. There is a need for qualification of health professionals dealing with abused women in order to identify the presence of TMD and OFP as well as depression and somatization.
\end{abstract}

Key words: Temporomandibular disorders; orofacial pain, domestic violence

\section{Resumo}

Objetivo: Os objetivos deste estudo foram o de avaliar a prevalência de Disfunção TêmporoMandibular e Dor Orofacial (DTM e DOf) em mulheres vítimas de violência, e o impacto da dor crônica nos fatores psicossociais relacionados, como depressão e somatização, e na qualidade de vida das mulheres.

Metodologia: Uma amostra de conveniência de 20 mulheres em situação de violência doméstica que acessam instituições de apoio foram entrevistadas volutariamente. A dor orofacial e fatores psicossociais relacionados foram avaliados pelo RDC/DTM (Critério de Diagnóstico para Pesquisa das Desordens Temporomandibulares) Eixo Il, e a história de abuso físico e social pelo S/PAHQ (Questionário sobre História de Abuso Físico e Sexual).

Resultados: Oitenta por cento das mulheres vítimas de violência mostraram dor crônica, variando de 1 a 3 em uma escala de quarto ítens (0 to 3), 65\% demonstraram depressão severa, e 60 e $70 \%$, somatização severa com ou sem dor, respectivamente. Adicionalmente, $85 \%$ relataram dor na face, têmporas e ouvido no ultimo mês com uma padrão recorrente.

Conclusão: Os dados indicaram alta prevalência de DTM e DOf nesta amostra. Há necessidade de qualificação de profissionais de saúde que atendam mulheres agredidas a fim de identificar a presença de DTM e DOf, bem como depressão e somatização.

Palavras-chave: Disfunção têmporo-mandibular, dor orofacial, violência doméstica, violência contra a mulher

\author{
Patricia Saram Progiante ${ }^{\circ}$ \\ Denise Munaretto Ficht ${ }^{b}$ \\ Marlise Silva Lemos ${ }^{c}$ \\ Patricia Krieger Grossi d \\ Marcio Lima Grossi a
}

\begin{abstract}
- Graduate Program in Dentistry, Faculty of Dentistry, Pontifical Catholic University of Rio Grande do Sul, Porto Alegre, RS, Brazil

b Dental Course, Faculty of Dentistry, Pontifical Catholic University of Rio Grande do Sul, Porto Alegre, RS, Brazil

c Faculty of Education, Pontifical Catholic University of Rio Grande do Sul, Porto Alegre, RS, Brazil

¿Graduate Program in Social Work, Pontifical Catholic University of Rio Grande do Sul, Porto Alegre, RS, Brazil
\end{abstract}

\author{
Correspondence: \\ Márcio L. Grossi \\ Avenida Ipiranga 6681, Prédio 6 - sala 402 \\ Porto Alegre, RS - Brazi \\ 90619-900 \\ E-mail:mlgrossi@pucrs.br
}

Received: August 9, 2011

Accepted: September 23, 2011

Conflict of Interest Statement: The authors state that there are no financial and personal conflicts of interest that could have inappropriately influenced their work.

Copyright: (C) 2011 Progiante et al.; licensee EDIPUCRS. This is an Open Access article distributed under the terms of the Creative Commons AttributionNoncommercial-No Derivative Works 3.0 Unported License. 


\section{Introduction}

Violence against women has been the focus of different debates and studies aiming to assess the magnitude of the problem. It became an international issue when, in 1993, the United Nations General Assembly adopted the Declaration for the Elimination of Violence against Women. In 2002, the World Health Organization, by means of the World Report about Violence and Health, defined sexual violence against women as one of the health problems with the highest prevalence and major incidents, warning for the need of more studies, data collection and information that make it possible to estimate the magnitude and extent of the problem (1).

The health professionals, in general, have the first contact with the women who come to the health service showing signs and symptoms of violence. However, women tend to avoid telling the health professionals about the situation of violence they are in. The feeling of shame was described as one of the reasons for not talking about it $(2,3)$.

Psychosocial factors (e.g., depression, somatization and sleep problems) might exert a primary role in the development of temporomandibular disorders and orofacial pain (TMD and OFP) as well as in the treatment outcome. Therefore, they should be included as important diagnostic and prognostic factors in the treatment of TMD. In these studies, the patients who did not have a good treatment response (non-responding TMD), performed worse both in the memory and in the psychosocial tests (e.g., depression, fatigue, sleep and level of energy) than responding TMD patients, showing higher memory deficits, higher sleep disorders, higher depression and fatigue levels, and lower energy levels (4-6).

Consequently, the dentist responsible for the evaluation, diagnosis and treatment of orofacial pain must include psychosocial assessment when determining the etiology and the final treatment plan for TMD patients (6). The use of standard instruments in assessing the psychosocial history, including the history of violence, in chronic pain patients is necessary due the difficulty of disclosing them otherwise (7). Many patients may have difficulties in sharing information about current or previous psychiatric treatments, so we should take into consideration the possibility of consulting a psychologist, a psychiatrist or a social worker (8). The dentist must be aware, because regardless of the treatment used, around $80 \%$ of the TMD patients get better most likely due to the placebo effect. However, it is also clear that at least $20 \%$ of the patients do not get better and may be actually non-responding to treatment due to psychosocial factors $(5,9)$. In these $20 \%$, it is possible that we might find women who suffered either physical or sexual abuse, which might the underlying cause of their orofacial pain (10). The patients with a physical and sexual abuse history show very high levels of depression, and these ones have an important impact on the development and perpetuation of the chronic pain (11-13). The orofacial pain, most of the cases, is associated with the muscles of mastication and/or with the temporomandibular joint(s) (14).
Nowadays, it is understood that not only clinical factors (classic signs and symptoms of TMD, such as the degree of mouth opening, sensibility to palpation, pain at rest, etc.), but also systemic and psychosocial factors (e.g., physical and sexual abuse) may be considered as risk factors in the development of temporomandibular disorders (TMD) (4-6). Temporomandibular disorders (TMD) are characterized by a variety of symptoms including orofacial pain, which is frequently exacerbated by mandibular movements and particularly by mastication. Regarding the cost of treatment, temporomandibular disorders are the most prevalent painful conditions of non-dental origin and one of the most important reasons for patients seeking treatment. The estimated annual for chronic pain treatment in the USA is US\$ 66 billion dollars, and it is one of the main research areas of the National Institutes of Health/National Institutes of Dental Research (15).

Therefore, the objectives of this study were: a) to assess the prevalence of Temporomandibular Disorders and Orofacial Pain (TMD and OFP) by using RDC/TMD (Research Diagnostic Criteria for Temporomandibular Disorders) Axis II in women victim of domestic violence, and b) to correlate the self-report of chronic pain related psychosocial factors, such as depression and somatization, of the RDC/TMD Axis II with the history of sexual and physical abuse of the S/PAHQ (Sexual and Physical Abuse History Questionnaire) $(10,16)$.

\section{Methods}

Our sample was comprised of 20 women, who were in a situation of domestic violence and looked for the Support Institutions (Viva Maria Support Institution, Reference Center to Violence Victims, Women Reference Center Vânia Araújo Machado, in Porto Alegre, RS, Brazil). The participation was voluntary, without age limit or social and economic conditions; because of that, our sample was selected by convenience due to the limited number of subjects available and difficulty in disclosing the information. After signing an informed consent approved by the Institutional Ethics Committee (No. 06/03193), the research subjects underwent the application of two questionnaires for data collection. The respective questionnaires were used: a) the Research Diagnostic Criteria for Temporomandibular Disorders - RDC/TMD (Axis II) and the Sexual and Physical Abuse History Questionnaire (S/PAHQ) $(10,16)$.

The RDC/TMD Axis II measures the patient's selfassessment and the disability of chronic pain as well as the interaction between psychosocial correlates of chronic pain, such as depression and somatization (16). In relation to the data about the history of different forms of violence, its social and emotional impact as well as its implications, the Sexual and Physical Abuse History Questionnaire (S/PAHQ) was used (10). It has questions which were developed in order to obtain a population-based epidemiological survey about the history of physical and sexual abuse. The S/PAHQ was tested with good reproducibility and validity, and it also showed a very good agreement with data from history 
of sexual and physical abuse obtained in comprehensive clinical interviews. This questionnaire was used in several studies of physical and sexual abuse history in patients with chronic pain including Irritable Bowel Syndrome (IBS), Chronic Pelvic Pain, and Temporomandibular Disorders (TMD) $(7,11,12)$. In this study, the objective was not only to assess a collective dimension of the problem, but also an individual one of the impact of physical and sexual abuse. The questionnaires were applied in a private room inside the institution after patients have signed the consent form.

Data were analyzed by using descriptive statistics.

\section{Results and Discussion}

Our sample of battered women showed low levels of education ( $70 \%$ with elementary school only, $30 \%$ with high school, and none with post-secondary education), indicating a relationship of economic dependency between them and their partners, which has been consistently reported in our interviews. In addition to that, a significant portion of them $(41.6 \%)$ was found in a situation of economic vulnerability (unemployed) with major difficulties in entering the labor market. The average age of battered women was $34.7 \pm 11.1$ years old, and most of them had two or three children on average $(2.6 \pm 1.6)$. The majority of our sample was found separated from its partners $(65 \%)$; however, women had stayed in the relationship with their abusive partner on average for 14.8 years. In relation to more specific data, some relevant items were identified: a) the ethnic factor, half of the battered women did not consider themselves white (50\% black, indigenous, or racially mixed) against a white majority $(75 \%)$ in the Southern Brazilian general population (IBGE-Brazilian Government Statistics); b) the low social and economic status (41.6\% unemployed with an income with less than 5 minimum wages or 24,000 US dollars a year, and 20\% from rural areas); and c) the catholic religion (68.1\% roman catholics) interference towards the preservation of marriage (17).

The data agrees with the studies of Kronbauer \& Meneghel, who studied 251 women victim of violence between the age range of 18 and 49 assisted in a basic health unit in Porto Alegre, State of Rio Grande do Sul, Brazil (17). They demonstrated the association between low scholarity and violence. Adeodato et al. added that the scholarity of abused women presents an average of six years of study (3). In this perspective, Drezzet studying the victims assisted in the Service for Integral Attention to Sexually Victimized Women showed that low scholarity $(40 \%$ of battered women with incomplete elementary school) can be related to a situation of violence (18). According to Saffioti, "the role of the material need provider is unquestionably the most defining role of masculinity (19). When this status is lost, the man feels hit in his own virility, watching the subversion of domestic hierarchy". Therefore, unemployment keeps women from changing the situation. It becomes perceptible that different modalities of violence suffered by women do present intimate relation to race and religious aspects, because it is configured from a set of values that places the female sex in a submissive role.

Regarding the male partner's characteristics, some aspects were found: a) the significant majority of them presented higher educational level as compared to their female partners ( $85 \%$ with complete high school education), b) he was usually the main source of income, such as a formal job or retirement funds (only $14.28 \%$ unemployed), and c) the average age was higher $(52.4 \pm 21$ years old $)$ than battered women. This clearly indicated that the abusive situation could not be attributed to social and economic problems of the male partner, but by a model of power and control over the female one. According to Saffioti (1997), the violence that attacks a great percentage of women is established in the context of gender violence. The gender violence is related to abuse of power in private space - ideology of patriarchate that reproduces the idea of a structure of power that places the woman "in a natural inferior position". The gender consists in social relations, and the violence is constitutive in relations between men and women, historically tied to the patriarchal order of gender (19).

In relation to modalities of violence (Table 1) and its ways of commitment, the vast majority reported having suffered any form of violence in their lifetimes. There were frequent demonstrations of violence by means of verbal offences and insults, as well as humiliations. They evolved towards intimidation and then to physical violence, such as slapping and jerking. In addition, the women are forced to have sexual relations with degrading practices. This is in agreement with the studies of Schumacher \& Leonard who analyzed marital problems (20). They found that expressions of violence, such as physical and verbal aggression, over the first two years of marital union of 634 couples. It was verified that the verbal aggression precedes and is followed by physical violence making it part of routine coexistence. Saffioti stated that sexual violence does not recognize limits, occurring in populations of different social and economical developments, in public or private space, and at any stage of woman's life (19). This violence results in a complex problem of public health because, besides the psychological damage, risk of taking sexually transmissible diseases, it is verified the possibility of incidence of pregnancy after rape and genital and non-genital lesions.

In relation to TMD chronic pain and psychosocial correlates (Table 2), the significant majority presented high levels of chronic pain, ranging from mild to high intensity as described in the Axis II of the RDC/TMD. Nevertheless, the presence of pain did not correlate well with absence from work, most likely due to the need for generating income for the family. The data related to harmful consequences of recurrent chronic pain were presented with high levels of depression and somatization with and without pain, which indicated a very low quality of life, and both factors act as risk factors for further violence due to the lack of energy to change the situation. Our results are compatible with those of Fillingim et al., who found reports of physical or sexual abuse, which might the underlying cause of their orofacial pain in this patient group (19). 
Table 1. Reports of physical, verbal and/or sexual violence in women victims of domestic violence who searched support institutions according to the Sexual and Physical Abuse History Questionnaire (S/PAHQ).

\begin{tabular}{|c|c|}
\hline Dependent variables / unit or category & $\begin{array}{l}\text { Women victims } \\
\text { of violence } \\
(n=20)\end{array}$ \\
\hline $\begin{array}{l}\text { Her husband / partner insulted her (\%) } \\
\text { No } \\
\text { Yes }\end{array}$ & $\begin{array}{l}12.5 \\
87.5\end{array}$ \\
\hline $\begin{array}{l}\text { Depreciated / humiliated before other people (\% } \\
\text { No } \\
\text { Yes }\end{array}$ & $\begin{array}{l}25 \\
75\end{array}$ \\
\hline $\begin{array}{l}\text { Scared or intimidated her (\%) } \\
\text { No } \\
\text { Yes }\end{array}$ & $\begin{array}{l}18.7 \\
81.2\end{array}$ \\
\hline $\begin{array}{l}\text { Hit her or tossed something at her (\%) } \\
\text { No } \\
\text { Yes }\end{array}$ & $\begin{array}{l}18.7 \\
81.2\end{array}$ \\
\hline $\begin{array}{l}\text { He pushed or shaked her (\%) } \\
\text { No } \\
\text { Yes }\end{array}$ & $\begin{array}{l}18.7 \\
81.2\end{array}$ \\
\hline $\begin{array}{l}\text { Forced her to have sexual relations with him (\%) } \\
\text { No } \\
\text { Yes }\end{array}$ & $\begin{array}{l}60 \\
40\end{array}$ \\
\hline $\begin{array}{l}\text { Obligated her to have sexual relation with him } \\
\text { by fear (\%) } \\
\text { No } \\
\text { Yes }\end{array}$ & $\begin{array}{l}40 \\
60\end{array}$ \\
\hline $\begin{array}{l}\text { Obligated her to have humiliating / degrading } \\
\text { sex (\%) } \\
\text { No } \\
\text { Yes }\end{array}$ & $\begin{array}{l}40 \\
60\end{array}$ \\
\hline $\begin{array}{l}\text { Consider having suffered any violence in life (\%) } \\
\text { No } \\
\text { Yes }\end{array}$ & $\begin{array}{c}5 \\
95\end{array}$ \\
\hline $\begin{array}{l}\text { Searched for any service (\%) } \\
\text { No } \\
\text { Yes }\end{array}$ & $\begin{array}{l}38.8 \\
61.1\end{array}$ \\
\hline
\end{tabular}

In relation to orofacial pain, temporomandibular disorders, and TMD correlates, the majority of battered women presented orofacial pain in the last month $(85 \%)$, with a recurrent pattern $(87.5 \%)$ with no help of a health professional (64.7\%). Other signs and symptoms of TMD were also frequent, such as TMJ locking (30\%), cliking (71\%), crepitation $(46.4 \%)$, pain or stiffness in the jaw in the morning $(76.8 \%)$, tinnitus $(71 \%)$, uncomfortable bite $(68.1 \%)$, headaches and migraines $(97.1 \%)$, awaked bruxism (55\%), and sleep bruxism (55\%).

Regarding the impact of domestic violence in the women's quality of life, many of them had problems in chewing (55\%), drinking (35\%), exercising $(10.5 \%)$, chewing hard $(60 \%)$ and soft foods $(21.1 \%)$, smiling/ gagging (35\%), sexual activity (5.4\%), cleaning teeth or face $(40 \%)$, yawning $(30 \%)$, swallowing $(26.4 \%)$, talking $(25 \%)$, and personal look (40\%). In this perspective, violence resulted in numerous afflictions to women's life. The demonstration(s) of violence can be identified in the development of chronic pains, which limits the quality of
Table 2. Results of RDC/TMD Axis II for orofacial pain characteristics, pain impact and associated psychosocial variables for women victims of domestic violence who searched support institutions according to the Research Diagnostic Criteria for Temporomandibular Disorders (RDC/TMD).

\begin{tabular}{|c|c|}
\hline Dependent variables / units or categories & $\begin{array}{l}\text { Women victims } \\
\text { of violence } \\
(n=20)\end{array}$ \\
\hline $\begin{array}{l}\text { Chronic Pain Grade (\%) } \\
\text { No pain }=0 \\
\text { Mild Severity }=1 \\
\text { Moderate Severity = } 2 \\
\text { High Severity }=3\end{array}$ & $\begin{array}{l}20 \\
30 \\
20 \\
30\end{array}$ \\
\hline $\begin{array}{l}\text { Disability Points }(\%) \\
\text { No or Mild Disability }(<3 \text { points }) \\
\text { High Disability }(3+\text { points })\end{array}$ & $\begin{array}{l}90 \\
10\end{array}$ \\
\hline $\begin{array}{l}\text { Characteristic Pain Intensity } \\
\text { Average (Standard Deviation) }\end{array}$ & 63.4 (21.9) \\
\hline $\begin{array}{l}\text { Depression } \\
\text { Average (Standard Deviation) }\end{array}$ & $2.5(0.70)$ \\
\hline $\begin{array}{l}\text { Non-Specific Physical Symptoms } \\
\text { (pain items included) } \\
\text { Average (Standard Deviation) }\end{array}$ & $1.6(0.5)$ \\
\hline $\begin{array}{l}\text { Non-Specific Physical Symptoms } \\
\text { (pain items not included) } \\
\text { Average (Standard Deviation) }\end{array}$ & $1.3(0.8)$ \\
\hline $\begin{array}{l}\text { Depression (\%) } \\
\text { Mild Depression }(<0.535) \\
\text { Moderate Depression (from } 0.535 \text { to }<1.105) \\
\text { Severe Depression }(1.105+\text { ) }\end{array}$ & $\begin{array}{c}5 \\
30 \\
65\end{array}$ \\
\hline $\begin{array}{l}\text { Non-Specific Physical Symptoms } \\
\text { (pain items included) }(\%) \\
\text { Mild Somatization }(<0.500) \\
\text { Moderate Somatization (from } 0.500 \text { to }<1.000) \\
\text { Severe Somatization }(1.000+)\end{array}$ & $\begin{array}{l}15 \\
15 \\
70\end{array}$ \\
\hline $\begin{array}{l}\text { Non-Specific Physical Symptoms } \\
\text { (pain items not included) }(\%) \\
\text { Mild Somatization }(<0.428) \\
\text { Moderate Somatization (from } 0.428 \text { to }<0.857 \text { ) } \\
\text { Severe Somatization }(0.857+\text { ) }\end{array}$ & $\begin{array}{l}15 \\
25 \\
60\end{array}$ \\
\hline
\end{tabular}

life as has also been described previously in the Brazilian and international literature $(3,10-12)$.

\section{Conclusions}

The results of our study clearly indicate that women victim of domestic violence who seek help in support institutions do have signs and symptoms of chronic temporomandibular disorders as well as high levels of depression and somatization with and without pain as measured by the RDC/TMD (Research Diagnostic Criteria for Temporomandibular Disorders) Axis II. In addition, levels of violence did correlate well with self-reports of verbal, sexual and physical abuse as measured by the $\mathrm{S}$ / PAHQ (Sexual and Physical Abuse History Questionnaire). The major risk factors for women to continue in an abusive relationship were poor level of education, economic dependency, religious beliefs, low self-esteem and selfreliance, and number of children. 
With regard to the results of this study, it is highlighted the relevance of heading a sensitive perspective to the latent demands which are the need of implementation of public policies. These policies should be directed towards the empowerment of women in order to allow them access to education, financial autonomy, economic integration programs, and programs to support families. The data provided indicate that there is also the need to train health professionals who deal with chronic pain patients to identify cases where domestic violence is present and to correctly refer them to the appropriate violence prevention service.

\section{Acknowledgments}

This study was supported by the PUCRS-PRAIAS research grant.

References 1. World Health Organization. Active aging: a health policy. $1^{\text {st }}$ ed. Brasilia: World Health Organization and Pan American Health Organization; 2005.

2. Diniz SG, D'Oliveira AF. Gender violence and reproductive health. Int J Gynaecol Obstet 1998;63 Suppl 1:S33-42.

3. Adeodato VG, Carvalho RR, Siqueira VR, Souza FGM. Qualidade de vida e depressão em mulheres vítimas de seus parceiros. Rev Saúde Pública 2005;39:108-13.

4. Goldberg M \& Grossi ML: Refractory temporomandibular disorders: Understanding and treating the chronic facial pain patient. Alpha Omegan 1998;91:38-43.

5. Grossi ML, Goldberg MB, Locker D, Tenenbaum HC. Reduced neuropsychologic measures as predictors of treatment outcome in patients with temporomandibular disorders. J Orofacial Pain 2001;15:329-39.

6. Selaimen C, Jeronymo JCM, Brilhante DP, Grossi ML. Sleep and depression as risk indicators for temporomandibular disorders in a cross-cultural perspective: A case-control study. Int J Prosthodont 2006;19:154-61.

7. Drossman DA, Leserman J, Nachman G, Li Z, Gluck H, Toomey TC, Mitchel M. Sexual and physical abuse in women with functional or organic gastrointestinal disorders. Ann Intern Med 1990;1 13:828-33.

8. Goldberg RT: Childhood abuse, depression, and chronic pain. Clin J Pain 1994;10: 277-81.

9. Greene CS, Laskin DM: Long-term evaluation of treatment of myofascial pain-dysfunction syndrome: A comparative analysis. J Am Dent Assoc 1983;107:235-38.

10. Fillingim RB, Maixner W, Sigurdsson A, Kincaid S. Sexual and physical abuse history in subjects with temporomandibular disorders: Relationship to clinical variables, pain sensitivity, and psychologic factors. J Orofacial Pain 1997;1 1:48-57.

11. Toomey TC, Hernandez JT, Gittelman DF, Hulka JF: Relationship of physical abuse to pain and psychological assessment variables in chronic pelvic pain patients. Pain 1993;53:105-9.

12. Toomey TC, Seville JL, Mann JD, Abashian SW, Grand J: Relationship of sexual and physical abuse to pain description, coping, psychological distress, and health-care utilization in a chronic pain sample. Clin J Pain 1995;11:307-15.

13. Wurtele SK, Kaplan GM, Keairnes M. Childhood sexual abuse among chronic pain patients. Clin J Pain 1990;6:110-3.

14. Laskin D, Greenfield W, Gale E et al. (eds). The president's conference on the examination, diagnosis and management of temporomandibular disorders. Chicago: American Dental Association; 1983.

15. Ogden TE. Research Proposals: A Guide to Success. New York: Raven Press; 1991.

16. Dworkin SF, Leresche L (eds). Research Diagnostic Criteria for Temporomandibular Disorders. J Craniomandibular Disord Facial Oral Pain 1992;6:301-55.

17. Kronbaver, José Fernando Dresch and Meneghel, Stela Nazareth. Perfil da violência de gênero perpetrada por companheiro. Rev. Saúde Pública 2005;39:695-701.

18. Drezett JF. Study of factors related with sexual violence against children, adolescents, and adult women. [Doctoral Thesis]. São Paulo (SP): Centro de Referência da Saúde da Mulher e de Nutrição, Alimentação e Desenvolvimento Infantil; 2000.

19. Saffioti, Heleieth I. B. No Fio da Navalha: violência contra crianças e adolescentes no Brasil. In: Reicher, F. (org.). Quem Mandou Nascer Mulher? São Paulo: Agora Ltda; 1997. p.72-81

20. Schumacher JA, Leonard KE. Husband's and wive's marital adjustment, verbal aggression, and physical aggression as longitudinal predictors of physical aggression early marriage. J Consult Clin Psychol 2005; 73:28-37. 